\title{
Biodiversity and Endangered Species: Issues of Significance
}

\section{Michael Campbell*}

Lakehead University, Ontario, Canada

Biodiversity, endangered species and conservation policy are globally relevant, biological, geographical, socio-economic and political topics involving the global media, scientists and the wider academic, policy and practitioner communities $[1,2]$. Issues relevant to biodiversity include deforestation, global warming, urban growth, conservation, sustainable development and green/brown issue conflicts $[3,4]$. Contrasts emerge between the dominant topics relevant to the North (the industrialized nations of North America, Europe and Asia) and the South (the so-called developing countries of South America, Africa and Asia). Issues of greatest interest in the north include environmental movements, suburban landscape change, post industrialism and the socio-environmental significance of the mass consumerist culture [5]. In contrast, issues of concern to the South include deforestation, desertification, soil erosion, population growth and urban expansion, and the associated socio-environmental impacts of famine, poverty, social upheavals and national stability [6].

Recent developments in ecology have sought to incorporate these issues. One focus is the increased attention to integrated environmental history, with offshoots towards human livelihoods, biogeography and political ecology [6-8]. There is also a greater attention to scale, structure, agency, allowing the documentation of nonlinear interactions and their contribution to the creation of patterns at small and large scales $[1,5,9]$.

Some of these studies might be termed multidisciplinary or hybrid methodologies - the main strength of biodiversity studies incorporating data and research methods from the documentation of economic, political, social change, as well as environmental dynamics. Topics include agricultural change [9-13] soils management [14] livestock and rangelands [15-17] mountain systems [8] national parks and wildlife issues $[2,18]$ and water management [19-21]. The combination of these subjects appears daunting, but comprises the basis upon which a viable biodiversity study must be based.

\section{References}

1. Hanna KS, Clark DA, Slocombe SD (2008) Transforming Parks and Protected Areas: Policy and Governance in a Changing World. Routledge, New York, USA.

2. Linnell JDC, Swenson JE, Andersen R (2001) Predators and people: conservation of large carnivores is possible at high human densities if management policy is favorable. Animal Conservation 4: 345-349.

3. Pretty J, Smith D (2004) Social capital in biodiversity conservation and management. Conservation Biology 18: 631-638.

4. Woodroffe R, Thirgood S, Rabinowitz A (2005) People and Wildlife, Conflict or Coexistence? Cambridge University Press, Cambridge, UK.

5. Pomeroy JY (2012) Analyzing Municipal Annexations: Case Studies of Frederick and Caroline Counties of Maryland 1990 - 2010. Unpublished PhD Thesis, University of Maryland, College Park, USA

6. Scoones I (2009) Livelihoods perspectives and rural development. J Peasant Stud 36: 171-196.

7. Walker P (2005) Political ecology: where is the ecology? Progress in Human Geography 29: 73-82.

8. Collins TW (2008) The political ecology of hazard vulnerability: marginalization, facilitation and the production of differential risk to urban wildfires in Arizona's White Mountains. Journal of Political Ecology 15: 21- 43.

9. Campbell M (2008) A new zoogeography of domestication and agricultural planning in Southern Ghana. Area 41: 139-148.
10. De Molina MG (2013) Agroecology and Politics. How to Get Sustainability? About the Necessity for a Political Agroecology 37: 45- 49.

11. Mortimore MJ (2009) Dryland Opportunities: A new paradigm for people ecosystems and development IUCN, Gland, Switzerland; IIED, London and UNDP/DDC, Nairobi, Kenya.

12. Campbell M, Torres-Alvarado M (2011) Public perceptions of jaguars Panthera onca, pumas Puma concolor and coyotes Canis latrans in El Salvador. Area 43: $250-256$

13. Ndah NR, Asaha S, Hyacinth M, Yengo T, Egbe AE, et al. (2012) Distribution of mammals and hunting practices in Okpambe and Assam areas of the Takamanda Rainforest, South-West Cameroon. Journal of Soil Science and Environmental Management 3: 252-261.

14. Khumalo G, Holechek J, Thomas M, Molinar F (2008) Soil depth and climatic effects on desert vegetation dynamics. Rangeland Ecology \& Management 61: 269-274.

15. Brandon T, Bestelmeyer, Estell RE, Havstad KM (2012) Big questions emerging from a century of rangeland science and management. Rangeland Ecology \& Management 65: 543-544.

16. Brunson MW (2012) The elusive promise of social-ecological approaches to rangeland management. Rangeland Ecology and Management 65: 632-637.

17. Sayre NF, deBuys W, Bestelmeyer BT, Havstad KM (2012) "The range problem" after a century of rangeland science: new research themes for altered landscapes. Rangeland Ecology and Management 65: 545-552.

18. Hayward MW, Somers MJ (2009) Reintroduction of top-order predators Conservation Science \& Practice, Wiley-Blackwell, Oxford, UK.

19. Falkenmark M (2004) Towards integrated catchment management: opening the paradigm locks between hydrology, ecology and policy-making. International Journal of Water Resources Development 20: 275-281.

20. Braga B, Varella P, Gonçalves H (2011) Transboundary Water Management of the Amazon Basin. International Journal of Water Resources Development 27: 477-496.

21. Mulligan BM, Eckstein GE (2011) The Silala/Siloli watershed: dispute over the most vulnerable basin in South America. International Journal of Water Resources Development 27: 595-606.

*Corresponding author: Michael Campbell, Lakehead University, Ontario, Canada, Tel: 250220 3434; E-mail: ecol55@hotmail.com

Received December 28, 2012; Accepted December 28, 2012; Published December 31, 2012

Citation: Campbell M (2012) Biodiversity and Endangered Species: Issues of Significance. J Biodivers Endanger Species 1:e102. doi:10.4172/23322543.1000e102

Copyright: (C) 2012 Campbell M. This is an open-access article distributed unde the terms of the Creative Commons Attribution License, which permits unrestricted use, distribution, and reproduction in any medium, provided the original author and source are credited. 